L. Larsen • J. Størling • M. Darville • D. L. Eizirik •

C. Bonny $\cdot$ N. Billestrup $\cdot$ T. Mandrup-Poulsen

\title{
Extracellular signal-regulated kinase is essential for interleukin-1-induced and nuclear factor KB-mediated gene expression in insulin-producing INS-1E cells
}

Received: 20 May 2005 / Accepted: 21 July 2005 / Published online: 11 November 2005

C) Springer-Verlag 2005

\begin{abstract}
Aims/hypothesis: The beta cell destruction and insulin deficiency that characterises type 1 diabetes mellitus is partially mediated by cytokines, such as IL- $1 \beta$, and by nitric oxide (NO)-dependent and -independent effector mechanisms. IL-1 $\beta$ activates mitogen-activated protein kinases (MAPKs), including extracellular signal-regulated kinase (ERK), p38 and c-Jun $\mathrm{NH}_{2}$-terminal kinase (JNK), and the nuclear factor kappa B (NFkB) pathway. Both pathways are required for expression of the gene encoding inducible nitric oxide synthase (iNOS) and for IL-1 $\beta$ mediated beta cell death. The molecular mechanisms by which these two pathways regulate beta cell Nos2 expression are currently unknown. Therefore, the aim of this study was to clarify the putative crosstalk between MAPK and NFKB activation in beta cells. Materials and methods: The MAPKs ERK, p38 and JNK were inhibited by SB203580, PD98059 or Tat-JNK binding domain or by cells overexpressing the JNK binding domain. The effects of MAPK inhibition on IL-1 $\beta$-induced iNOS production and kappa $\mathrm{B}$ inhibitor protein (IKB) degradation were examined by western blotting. NFKB DNA binding was investigated by electrophoretic mobility shift assay, while
\end{abstract}

L. Larsen · J. Størling · N. Billestrup · T. Mandrup-Poulsen ( $\bowtie)$ Steno Diabetes Center,

2 Niels Steensens Vej,

2820 Gentofte, Denmark

e-mail: tmpo@steno.dk

Tel.: +45-44-439101

Fax: $+45-44-438232$

M. Darville · D. L. Eizirik

Laboratory of Experimental Medicine,

Université Libre de Bruxelles,

Brussels, Belgium

C. Bonny

Lausanne University,

Lausanne, Switzerland

T. Mandrup-Poulsen

Department of Molecular Medicine, Karolinska Institute,

Stockholm, Sweden
NFKB-induced gene transcription was evaluated by gene reporter assays. Results: Inhibition of the MAPKs did not affect IKB degradation or NFKB DNA binding. However, inhibition of ERK reduced NFKB-mediated Nos2 expression; serine 276 phosphorylation of the p65 unit of the NFKB complex seemed critical, as evaluated by amino acid mutation analysis. Conclusions/interpretation: ERK activity is required for NFKB-mediated transcription of Nos2 in insulin-producing INS-1E cells, indicating that ERK regulates Nos 2 expression by increasing the transactivating capacity of NFKB. This may involve phosphorylation of Ser276 on p65 by an as yet unidentified kinase.

Keywords Pancreatic beta cells $\cdot$ IL- $1 \beta \cdot$ Mitogenactivated protein kinases - Nuclear factor kappa B - Type 1 diabetes $\cdot$ Nitric oxide

Abbreviations CBP: CREB-binding protein - EMSA: electrophoretic mobility shift assay - ERK: extracellular signal-regulated kinase $\cdot \mathrm{I} \kappa \mathrm{B} \alpha$ : inhibitor protein kappa $\mathrm{B}$ alpha - iNOS: inducible nitric oxide synthase - JBD: JNKbinding domain $\cdot \mathrm{JNK}$ : c-Jun $\mathrm{NH}_{2}$-terminal kinase $\cdot$ MAPK: mitogen activated protein kinase $\cdot$ MSK1: mitogen- and stress-activated kinase $1 \cdot \mathrm{NF} \kappa \mathrm{B}$ : nuclear factor kappa B - NO: nitric oxide - PKA: protein kinase A . RSK1/2: $90 \mathrm{kDa}$ ribosomal S6 kinase 1/2

\section{Introduction}

IL- $1 \beta$ is cytotoxic to rodent beta cells, causing inhibition of glucose-stimulated insulin secretion [1-3] and expression of the gene (Nos2) encoding inducible nitric oxide synthase (iNOS), which leads to nitric oxide (NO) formation $[1,4]$ and cell death by necrosis and apoptosis [5-9]. In human islets a combination of the proinflammatory cytokines IL$1 \beta$ and IFN $\gamma$ or TNF $\alpha$ is required to induce beta cell death, which occurs mainly by apoptosis [7].

The key signalling pathways activated by IL- $1 \beta$ in beta cells are the mitogen-activated protein kinase (MAPK) and the nuclear factor kappa B (NFKB) pathways $[10,11]$. 
The MAPKs comprise extracellular signal-regulated kinase (ERK), p38 and c-Jun $\mathrm{NH}_{2}$-terminal kinase (JNK). MAPK activation is augmented in beta cells compared with non-beta cells, and this is correlated with increased susceptibility to IL-1 $\beta$ toxicity $[1,6,12,13]$. We have previously demonstrated that ERK and p38 are necessary, albeit not sufficient, to cause NO formation [1], and inhibition of ERK or p38 reduces cytokine-induced beta cell death $[12,14]$. The JNK-dependency of IL- $1 \beta$-induced beta cell death has been substantiated, as overexpression of the natural cellular inhibitor and scaffold protein of JNK, islet-brain 1 (IB1), or of the JNK-binding domain (JBD) of IB1 prevents IL- $1 \beta$-induced beta cell apoptosis $[5,6$, $8,15]$.

NFKB comprises a collection of dimers composed of various combinations of members of the Rel family. Five mammalian Rel proteins have been identified: p50, p52, cRel, p65 (RelA) and RelB. Prior to cytokine exposure, NFKB is sequestered in the cytoplasm by binding to inhibitor protein kappa $\mathrm{B} \alpha(\mathrm{I} \kappa \mathrm{B} \alpha)$. Following cytokine exposure, I $\mathrm{K} B \alpha$ is phosphorylated, ubiquitinated and degraded by the proteasomal complex, liberating NFkB to translocate to the nuclear compartment and bind $\mathrm{kB}$ consensus sequences in promoter regions of numerous proinflammatory genes [16]. IL-1 $\beta$ activates the transcription factor NFKB in rodent [17] and human [18] islet cells, and blocking NFKB activation prevents cytokine-induced apoptosis in these cells [10].

p65, the most transcriptionally active NFKB subunit, can be phosphorylated on several serine residues, including Ser529, 536 and 276, by various kinases depending on the inducing stimulus [19-26]. These phosphorylations can regulate $\mathrm{NF} \kappa \mathrm{B}$ activity at various levels, including $\mathrm{p} 65$ and I $\mathrm{B} \alpha \alpha$ interactions, kinetics of p65 nuclear import, DNAbinding, cofactor association and transactivation [27-32].

MAPK activation augments NFKB activity in many cell types [22, 33, 34] but the interactions between these two key signalling pathways remain to be clarified in pancreatic beta cells. Therefore, we investigated whether MAPKs potentiate IL- $1 \beta$-induced NFKB activity in beta cells, and the mechanisms involved in this effect. This information is of relevance to understanding the particular susceptibility of pancreatic beta cells to cytokine-induced apoptosis [7, 35].

\section{Materials and methods}

Reagents

All reagents were from Sigma (Sigma Aldrich, San Diego, CA, USA) unless otherwise specified. Recombinant mouse IL-1 $\beta$ (specific activity: $[0.5-1.5] \times 10^{7} \mathrm{U} / \mathrm{mg}$ ) was from BD Pharmingen (Erembodegen, Belgium). The concentrations of IL-1 $\beta$ used were based on our own dose-response studies.

The MAPK inhibitors SB203580, PD98059 and H89 were all from Calbiochem (EMD Biosciences, La Jolla, CA, USA). The efficiencies of the SB203580 and PD98059 concentrations used were verified in kinase assays and by western blotting (data not shown). The concentrations chosen were based on information previously obtained in rat islets showing complete inhibition of ERK and p38, respectively, without affecting the functionality of the islets [1]. Tat-JBD and the corresponding control, Tat, have been thoroughly characterised previously $[6,8]$.

\section{Cell culture}

INS-1E and bTC3 cells were grown as previously described [36]. INS-1E cells were a kind gift from C. Wollheim, Geneva [37]. These cells were used between passages 56 and 75. Of note, INS-1E cells have a wellpreserved response to cytokines between passages 56 and 84 , as evaluated by cytokine-induced $\mathrm{Nos} 2$ and $\mathrm{Ccl} 2$ (formerly known as $M C P-1$ ) mRNA expression and apoptosis (F. Ortis and D. L. Eizirik, unpublished data).

\section{Immunoblotting}

Cells were seeded in 12-well or $100-\mathrm{mm}$ dishes. At 80 $85 \%$ confluency, cells were preincubated for 30 min with various inhibitors followed by incubation with or without IL- $1 \beta$ for $20 \mathrm{~min}, 1 \mathrm{~h}$ or $6 \mathrm{~h}$. Cells were lysed in $20 \mathrm{mmol} / \mathrm{l}$ Tris (pH 7.5), $0.27 \mathrm{~mol} / 1$ sucrose, $1 \mathrm{mmol} / 1$ EDTA, $1 \mathrm{mmol} / 1$ EGTA, $1 \%$ Triton X-100, $5 \mathrm{mmol} / 1$ sodium pyrophosphate, $10 \mathrm{mmol} / 1$ sodium glycerolphosphate, $1 \mathrm{mmol} / 1$ benzamidine, $4 \mu \mathrm{g} / \mathrm{ml}$ leupeptin, $1 \mu \mathrm{mol} / 1$ dithiothreitol and $1 \mu \mathrm{mol} / 1$ sodium orthovanadate. The protein concentration was measured with the Bradford assay (Bio-Rad, Hercules, CA, USA); $15 \mu \mathrm{g}$ of protein was separated by gel electrophoresis according to manufacturer's protocol using $10 \%$ BisTris gels (Invitrogen, Carlsbad, CA, USA). Nitrocellulose membranes (Invitrogen) were handled as described elsewhere [36] and incubated with the following antibodies overnight: anti-IkB $\alpha$ (\#40903; Active Motif, Rixensart, Belgium), anti- $\beta$-tubulin (sc-5274) and anti-p65 (sc-372) (Santa Cruz Biotechnology, Santa Cruz, CA, USA), anti-phospho-MSK1 (\#9595; Cell Signaling, Beverly, MA, USA) and anti-iNOS (\#610332; BD Biosciences, San Jose, CA, USA). Horseradish peroxidase-linked antirabbit (\#7074) or anti-mouse IgG (\#7076) (Cell Signaling) were used as secondary antibody for $1 \mathrm{~h}$ at room temperature and the peroxidase activity was detected by enhanced chemiluminescence using either LumiGlo Reagent (Cell Signaling) or SuperSignal (Pierce, Rockford, IL, USA) and photosensitive films (Amersham Biosciences, Uppsala, Sweden).

\section{Electrophoretic mobility shift assay}

INS-1E cells or $\beta$ TC3 cells were grown to $80-85 \%$ confluency in 100-mm dishes. Medium was changed and cells were preincubated with inhibitors for $30 \mathrm{~min}$ prior to cytokine exposure for $1 \mathrm{~h}$. Nuclear extracts were prepared, 
and an electrophoretic mobility shift assay (EMSA) was carried out as described [36]. NFKB DNA binding was detected using a double-stranded oligonucleotide (NFKB: 5'agtcAGCTTCAGAGGGGACTTTCCGAGAGG-3'). Antip65 antibody (sc-372) (Santa Cruz Biotechnology) was used for supershift analysis.

\section{Gene reporter assay}

INS-1E cells $(250,000$ cells per well) were seeded in duplicate in 24-well dishes and preincubated for 2 days in complete media ( $\sim 80-85 \%$ confluency). On the day of transfection, medium was discarded and transient transfection was performed overnight according to the manufacturer's instructions, using Superfect (Qiagen, Hilden, Germany) and a total of $1 \mu \mathrm{g}$ plasmid DNA. NFKBdependent gene transcription was analysed by use of $0.4 \mu \mathrm{g}$ of the PathDetect NF KB cis-Reporting System (Strategene, San Diego, CA, USA), with the luciferase reporter gene selectively regulated by $5 \times$ synthetic $\mathrm{NF} \kappa \mathrm{B}$ promoter enhancer elements or $0.4 \mu \mathrm{g}$ of the Nos 2 construct encompassing the proximal $1,002 \mathrm{bp}$ of the rat Nos 2 promoter fused to a luciferase reporter gene, as previously described [38]. pMSK1-E and pMSK1(D565A)-E were kindly provided by L. Vermeulen, Ghent University, Ghent, Belgium [22], and were tested in various concentrations. pMT2 (empty vector), pMT2-HA-RSK1, pMT2-HA-RSK2, pMTHA-f-CA RSK2 and pMT2 HA-RSK2-DN were gifts from M. Frodin, BRIC, Copenhagen, Denmark [39], and were tested in various concentrations. Overexpression of these plasmids was verified in HEK293 cells, as was the kinase activity of RSK1/2. pGal4-p65 (LBMP 3438), pGal4p65S276C (LBMP 4644), pGal4-p65S536A (LBMP 4645) and pGal4-p65S529A (LBMP 4646) were purchased from Belgian Co-ordinated Collections of Micro-organisms and Laboratory of Molecular Biology-Plasmid-collection (BCCM/LMBP), Ghent, Belgium http://www.belspo.be/ bccm/lmbp.htm), and all the constructs were described by Vermeulen and colleagues [22]. In all gene reporter assays, cells were cotransfected with $0.2 \mu \mathrm{g}$ of an internal control Renilla plasmid (pRL-TK; Promega, Madison, WI, USA), and empty vector (pcDNA3; Invitrogen) was added to equal the amount of plasmid DNA used in the different experiments.

Following transfection, medium was changed and cells were cultured for $6 \mathrm{~h}$ in the presence of IL-1 $\beta$, washed twice in PBS and incubated with Passive Lysis Buffer (Promega) for $30 \mathrm{~min}$. The promoter activity was analysed using the Dual-Luciferase Reporter Assay System (Promega) according to the manufacturer's instructions.

\section{Statistical analysis}

All data are presented as mean \pm SEM of $n$ independent experiments. Statistical analysis was done using a paired Student's $t$ test and a $p$ value of less than 0.05 was considered significant.

\section{Results}

ERK is essential for IL- $1 \beta$-induced NFKB-mediated gene expression

First, we confirmed that inhibition of ERK or p38 individually had a minor effect on iNOS protein production, whereas combined inhibition markedly decreased IL$1 \beta$-induced iNOS production (Fig. 1a).

We then asked if inhibition of MAPK reduced NFKB signalling. As shown in Fig. 1b, we found no effect of inhibition of ERK or p38 on IL-1 $\beta$-induced degradation of $\operatorname{I} \kappa \beta \alpha$. The degradation of $\operatorname{I} \kappa B \alpha$ was maximal within the first 15 min of stimulation but subsequent NF $\kappa B$-mediated resynthesis of $I \kappa B \alpha$ led to the reappearance of $\operatorname{I\kappa } B \alpha$ (data not shown). We chose here to study $1 \mathrm{~h}$ of IL- $1 \beta$ stimulation, as $I \kappa B \alpha$ degradation is still evident at this time point, which also allowed us to examine NFkB DNA binding. This was done by EMSA using the nuclear fraction of the cell extracts (Fig. 1c). IL-1 $\beta$ clearly induced NFKB nuclear translocation and DNA binding but preculture with SB203580 or PD98059 did not affect IL-1 $\beta$ induced NFKB DNA binding activity, indicating that NFKB activation was not influenced at this level by ERK and p38 activity. The EMSA supershift analysis revealed that at least one of the components in the IL- $1 \beta$-activated NFKB DNA-binding complexes in clonal beta cells is the transcriptionally active p65 subunit.

The specificity and efficacy of the pharmacological inhibitors used was verified in kinase assays and by western blotting (data not shown). PD98059 and SB203580 inhibited their established targets with no effects on any of the other highly conserved members of the MAPK family (data not shown).

Transient transfection of cells with a Nos 2 promoter construct and exposed to SB203580 or increasing concentrations of PD98059 revealed that inhibition of ERK, but not of $\mathrm{p} 38$, inhibited basal transcription and dosedependently reduced IL-1 1 -stimulated Nos 2 expression (Fig. 1d). Being critical for cytokine-induced Nos2 expression [7], NFkB was an obvious candidate responsible for the observed effect. Therefore, a reporter assay was performed using an NFKB minimal promoter, and similar results were obtained. However, in contrast to the native Nos2 reporter construct, SB203580 had a small effect on its own and the PD98059-mediated decrease in luciferase activity was exceeded by a combination of the two MAPK inhibitors (Fig. 1e). These results indicate that p38 and particularly ERK are essential for IL- $1 \beta$-induced NFKB-mediated gene expression in beta cells by augmenting NF KB activity downstream of nuclear translocation and DNA binding.

In the human NOSA promoter the presence of an intact activator protein 1 (AP-1) site is important for cytokinestimulated NOS2A expression [40]. However, the various AP-1 binding sites identified in the rat Nos 2 promoter [41] differ in sequence compared with traditional AP-1 response elements, and mutating an assumed AP-1 site did not reduce but rather increased the IL-1 $\beta$-induced rat Nos 2 
a

$\begin{array}{lccccccccc}\mathrm{IL}-1 \beta & - & - & - & - & - & + & + & + & + \\ \mathrm{SB} & - & - & + & - & + & - & + & - & + \\ \mathrm{PD} & - & - & - & + & + & - & - & + & + \\ \mathrm{DMSO} & - & + & - & - & - & - & - & - & -\end{array}$

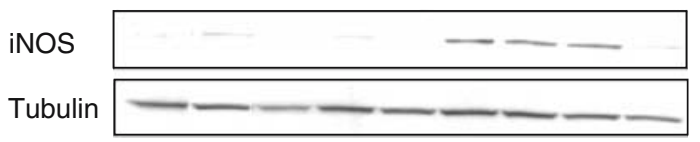

b

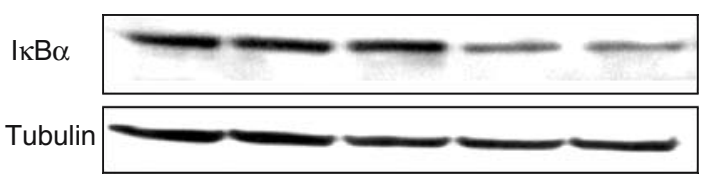

$\mathrm{IL}-1 \beta$

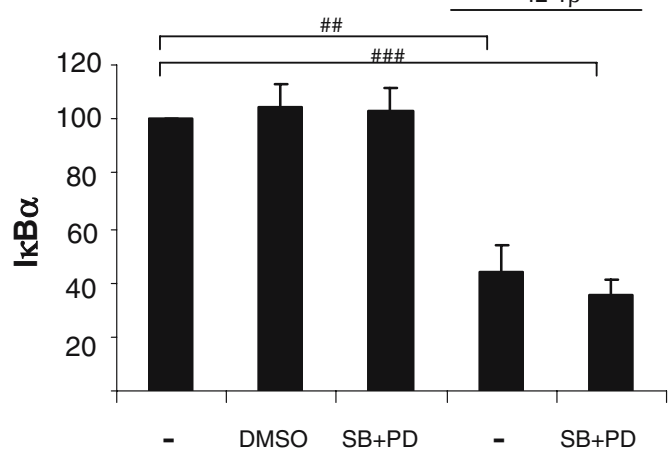

C

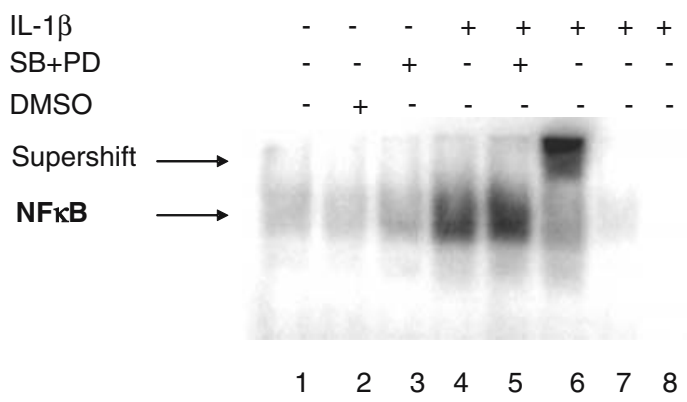

promoter activity from five- to 10 -fold compared with the unstimulated wild-type Nos 2 promoter construct (data not shown). Furthermore, the assumed AP-1 site competed very poorly with a traditional AP-1 site for AP-1 DNA binding in an EMSA (data not shown). These observations suggest that AP-1 does not participate in the regulation of rodent Nos 2 expression by binding to AP-1 like responseelements in the rat Nos 2 promoter.

\section{IL- $1 \beta$-induced degradation of I $\mathrm{B} \alpha$ occurs} independently of JNK activity

We next investigated if JNK was involved in the activation of NFKB. As seen in Fig. 2, inhibition of JNK activity by cell-permeable Tat-JBD fusion protein [8] or by over-
Fig. 1 Effect of ERK and p38 inhibition on NFKB activation. a INS-1E cells were precultured with SB203580 (SB; $10 \mu \mathrm{mol} / \mathrm{l})$, PD98059 (PD; $100 \mu \mathrm{mol} / 1$ ) or vehicle (DMSO) for $30 \mathrm{~min}$ followed by exposure to IL-1 $\beta(80 \mathrm{pg} / \mathrm{ml})$ for an additional $6 \mathrm{~h}$. Lysates were subjected to immunoblotting using antibodies against iNOS. A representative immunoblot is shown. b INS-1E cells were exposed to IL-1 $\beta(80 \mathrm{pg} / \mathrm{ml})$ for $1 \mathrm{~h}$ and western blotting was performed using the cytosolic fraction of the cell lysates and anti-IкB $\alpha$ antibody for immunoblotting. A representative immunoblot is presented above a graph showing mean protein expression \pm SEM compared with control and correlated to tubulin expression $(n=4)$. c An EMSA was performed on the nuclear fraction of cells using an NFKB-binding oligonucleotide as a probe. Supershifting was done with p65 antibody (lane 6 ) and specificity was examined by competition with a 100-fold (lane 7) or 1,000-fold (lane 8) excess of unlabelled specific probe. d-e INS-1E cells were transiently transfected with a Nos2/luciferase construct (d) or an NFKB/ luciferase construct (e) in addition to a control Renilla plasmid. Cells were precultured with SB203580 $(10 \mu \mathrm{mol} / \mathrm{l})$, PD98059 $(20,50$ or $100 \mu \mathrm{mol} / \mathrm{l}$ ) or a combination of both for $30 \mathrm{~min}$ and subsequently exposed to IL-1 $\beta(150 \mathrm{pg} / \mathrm{ml})$ for $6 \mathrm{~h}$. Data are presented as mean \pm SEM compared with IL-1 $\beta$-stimulated control $(n=4-5)$. ${ }^{*} p<0.05$, ${ }^{* *} p<0.01,{ }^{* * *} p<0.001$ vs IL-1 $\beta$ stimulated (black bars); ${ }^{*} p<0.05$, ${ }^{\# \#} p<0.01,{ }^{*}{ }^{\prime} p<0.001$ vs unstimulated (white bars); ${ }^{\dagger} p<0.05$ for PD980059 alone vs SB203580 and PD98059 in combination $(t$ test)

d

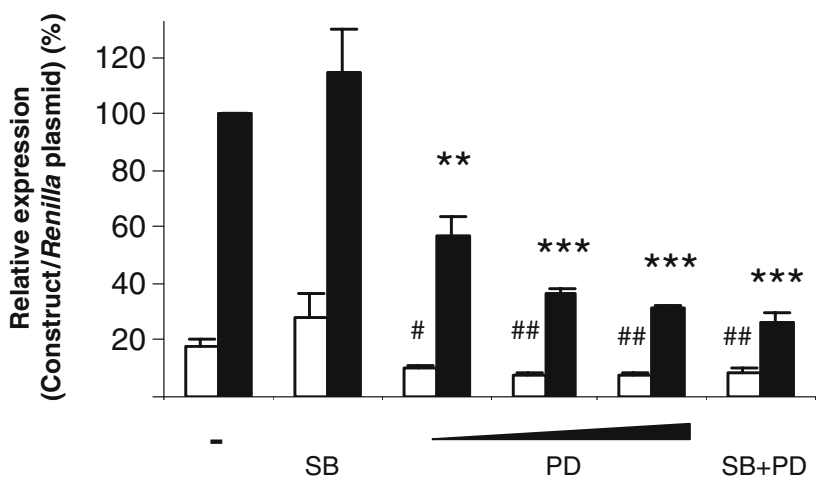

e

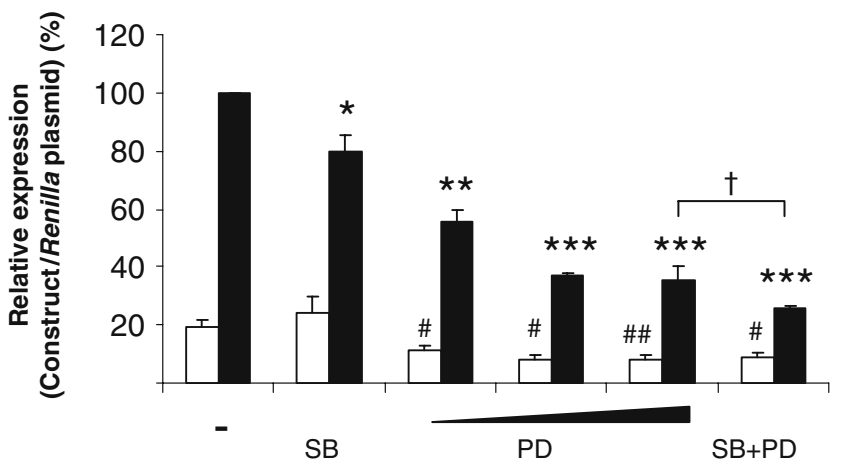

Fig. 1 (continued)

expression of JBD [6] did not prevent IL-1 $\beta$-induced degradation of I $\kappa \mathrm{B} \alpha$ (Fig. $2 \mathrm{a}$ ) or NFKB nuclear translocation and DNA binding (Fig. 2b). Similarly, preculture with Tat-JBD did not affect IL-1 $\beta$-induced, NFKB-mediated gene expression (Fig. 2c). A role for JNK in IL-1 $\beta$ mediated activation of NFKB can thus be excluded. 
a

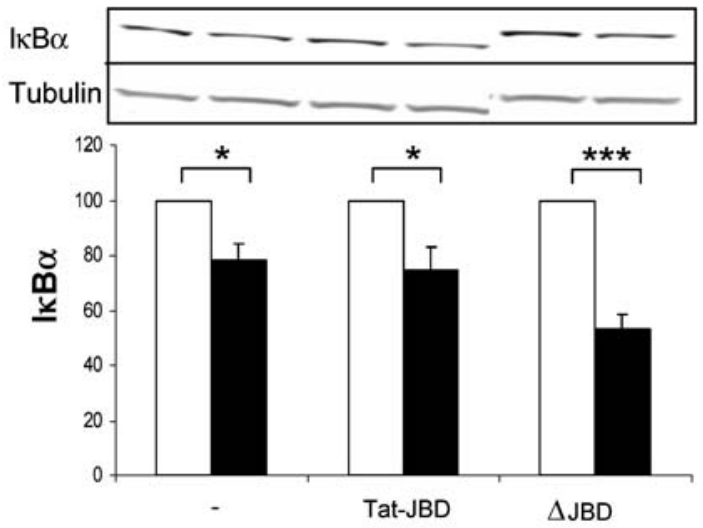

b

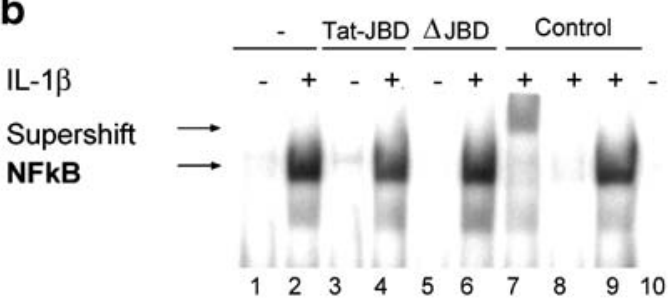

C

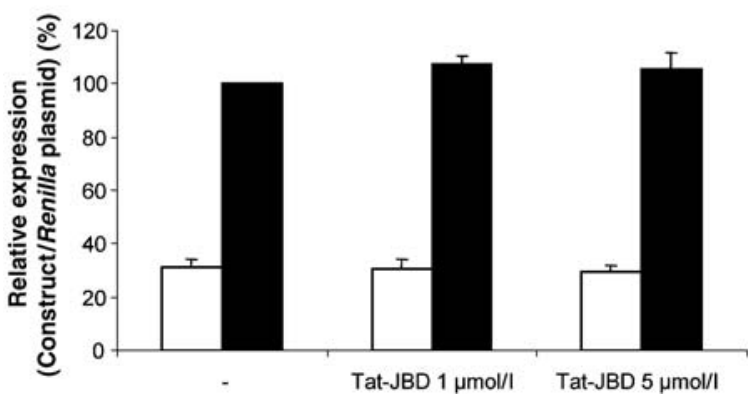

Fig. 2 Effect of JNK inhibition on NFKB activation. a $\beta T C 3$ control cells, $\beta$ TC 3 cells precultured for $30 \mathrm{~min}$ with Tat-JBD, and JBD-overexpressing cells $(\Delta \mathrm{JBD})$ were exposed to IL-1 $\beta(320 \mathrm{pg} /$ $\mathrm{ml}$ ) for $1 \mathrm{~h}$ (black bars) and lysed. The cytosolic fraction of the lysates was subjected to western blotting using anti-IкB $\alpha$ antibody. A representative immunoblot is presented above a graph showing the mean \pm SEM of stimulated (black bars) $(n=4)$ compared with unstimulated cells (white bars) and correlated to tubulin expression. $* p<0.05, * * * p<0.001$ ( $t$ test). b An EMSA was performed using the nuclear fraction of the cell lysates and an NFKB-binding oligonucleotide as a probe. Supershifting was done with anti-p65 antibody (lane 7) and specificity was examined by competition with 100 -fold excess of unlabelled specific (lane 8), unspecific (lane 9) or free probe (lane 10). c INS-1E cells were transiently cotransfected with an NFkB/luciferase construct and a control Renilla plasmid. Following preculture with Tat-JBD ( 1 or $5 \mu \mathrm{mol} / 1)$, cells were exposed to IL-1 $\beta(320 \mathrm{pg} / \mathrm{ml})$ for $6 \mathrm{~h}$ (black bars). Data are presented as mean and SEM compared with IL-1 $\beta$-stimulated control $(n=4)$

\section{ERK affects NFKB transactivation independently of MSK1 and RSK1/2}

Since ERK was the key MAPK responsible for increasing the NFKB transactivating capacity (see above) we next attempted to identify the ERK-regulated kinase responsible for this phenomenon. The $90 \mathrm{kDa}$ ribosomal S6 kinase,
RSK, was one of the first substrates of ERK to be discovered and has since proven to be a ubiquitous and versatile mediator of ERK signalling [42]. To investigate if this was also the case in insulin-producing cell lines, cells were transiently transfected with plasmids encoding wildtype forms of RSK1 and 2 as well as constitutive active forms, and the corresponding dominant negative form of RSK2. IL-1 $\beta$-induced Nos 2 promoter activity and NFkBmediated gene expression were not affected by any of these expression plasmids in a gene reporter assay (Fig. 3a and b, respectively).

Next, the RSK homologous kinase, mitogen and stress activated kinase 1 (MSK1), a substrate for both ERK and p38 [42], was investigated. Exposure of INS-1E cells to IL$1 \beta$ led to phosphorylation of MSK1 (Fig. 4a). This effect was primarily dependent upon p38 activity, as SB203580 but not PD98059 completely blocked MSK1 phosphorylation. Moreover, H89, a pharmacological inhibitor of MSK1, failed to suppress IL-1 $\beta$-induced NFKB-mediated gene expression in a gene reporter assay (Fig. 4b), in line with the finding that $\mathrm{H} 89$ had no effect on IL-1 $\beta$-induced iNOS protein production (Fig. 4c). H89 was originally developed as a specific inhibitor of protein kinase A (PKA) but has since been shown to inhibit the protein kinase

\section{a}

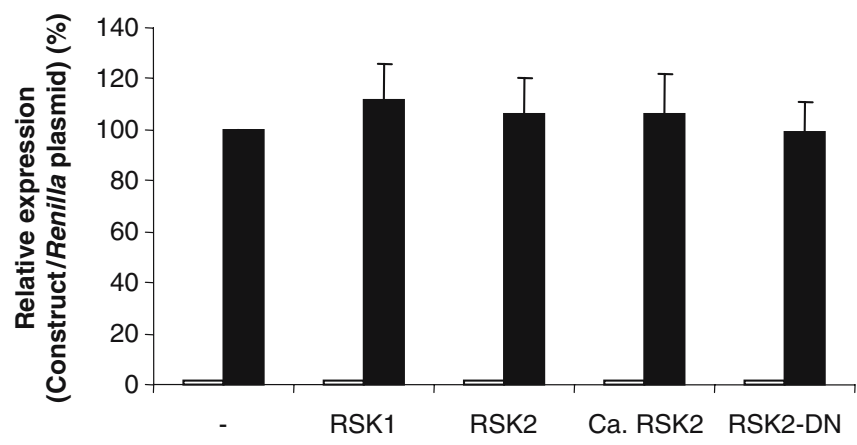

b

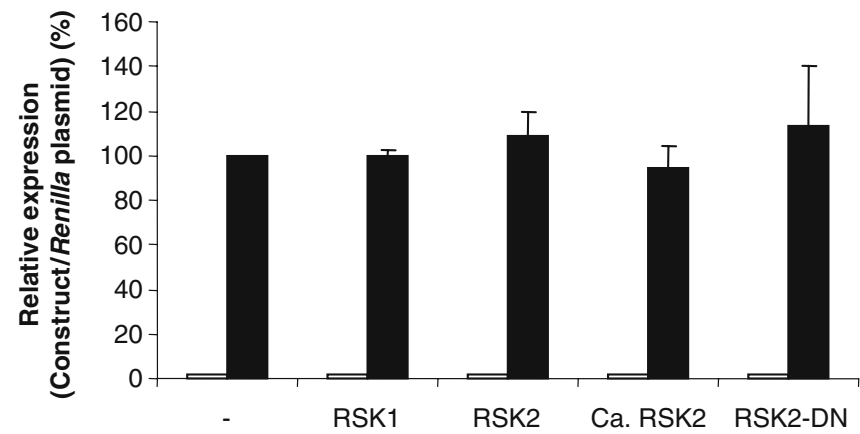

Fig. 3 Effect of overexpression of RSK or RSK-DN on NFkBmediated gene transcription. INS-1E cells were transiently cotransfected with plasmids encoding RSK1, RSK2, a constitutive active form of RSK2 (Ca.RSK2), or a dominant-negative form of RSK2 (RSK2-DN) and a control Renilla plasmid in combination with (a) a Nos2/luciferase construct or (b) an NFkB/luciferase construct. Cells were subsequently exposed to IL-1 $\beta(160 \mathrm{pg} / \mathrm{ml})$ for $6 \mathrm{~h}$ (black bars). Graphs are presented as mean \pm SEM compared with IL-1 $\beta$ stimulated control $(n=4)$ 
a

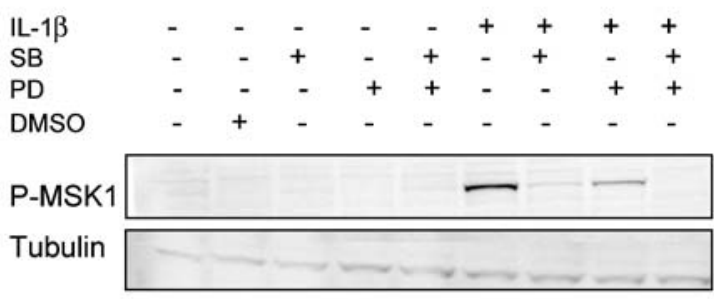

b

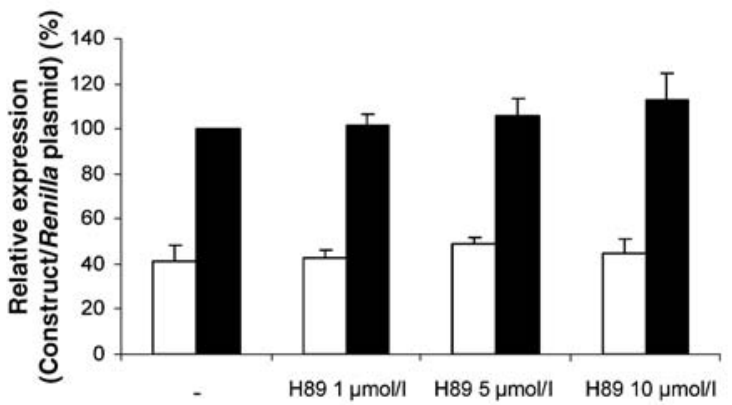

C

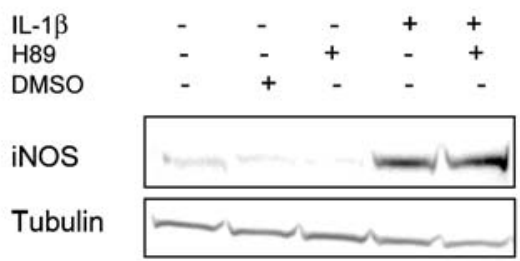

d
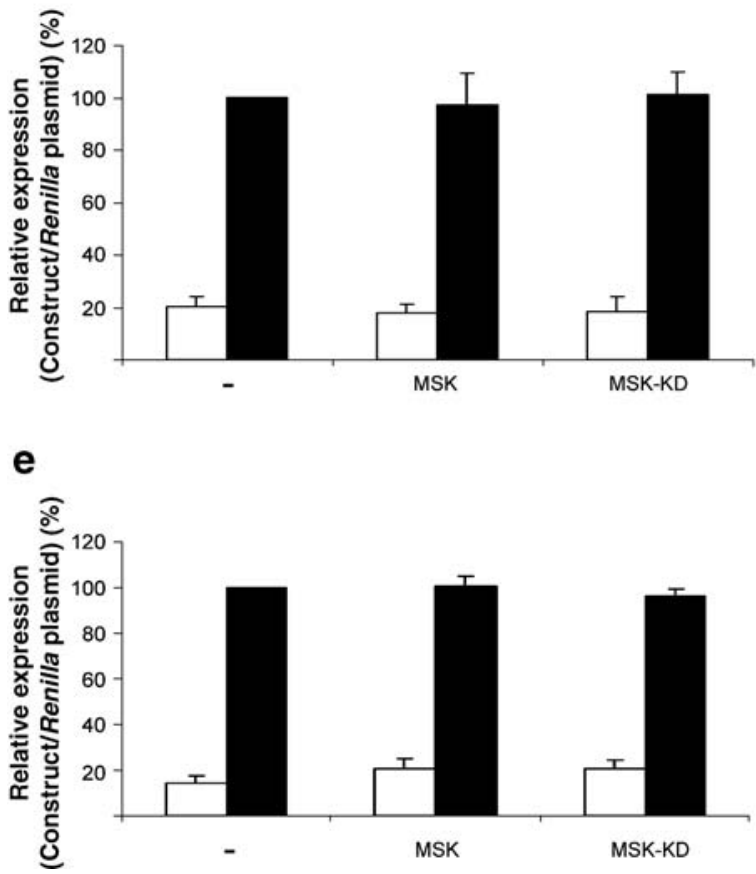

MSK1 with a potency even greater than that for PKA [43]. Since PKA has not been implicated in IL-1 signalling in beta cells, it is reasonable to assume that H89 inhibited MSK1. In addition, transient transfection with plasmids leading to overexpression of MSK1 or with a kinase-dead
Fig. 4 Effect of MSK1 on NFkB activation. a INS-1E cells were precultured with vehicle (DMSO) or the inhibitor SB203580 (SB $10 \mu \mathrm{mol} / 1$ ) or PD98059 (PD; $100 \mu \mathrm{mol} / 1$ ) alone or in combination for $30 \mathrm{~min}$ and subsequently exposed to IL-1 $\beta(320 \mathrm{pg} / \mathrm{ml})$ for a further $20 \mathrm{~min}$. Lysates were subjected to immunoblotting using antibodies against phospho-MSK1 (P-MSK1). A representative immunoblot is shown. b Following transient transfection of INS-1E cells with the NFKB/luciferase construct and a control Renilla plasmid, cells were precultured with increasing concentrations of H89 $(1,5$ or $10 \mu \mathrm{mol} / 1)$ for $30 \mathrm{~min}$ followed by exposure to IL-1 $\beta$ $(320 \mathrm{pg} / \mathrm{ml})$ for an additional $6 \mathrm{~h}$ (black bars). c Following prestimulation and subsequent cytokine stimulation, as previously, cells were lysed and subjected to immunoblotting using antibodies against iNOS. Representative immunoblots of four independent experiments are shown. d-e INS-1E cells were cotransfected with plasmids encoding the gene for either MSK1 (MSK) or a kinasedead form of MSK1 (MSK-KD) and a Renilla control plasmid in addition to (d) a Nos2/luciferase-construct or (e) an NFKB/luciferase construct. Cells were subsequently exposed to IL-1 $\beta(320 \mathrm{pg} / \mathrm{ml})$ for $6 \mathrm{~h}$ (black bars). Graphs are presented as mean \pm SEM compared with IL1- $\beta$-stimulated control $(n=3-4)$

mutant form of MSK1 did not interfere with IL-1 $\beta$ stimulated Nos 2 promoter activity (Fig. 4d) or NFKBmediated gene transcription (Fig. 4e).

Taken together, these results show that the observed effect of ERK on NFKB activity is mediated neither by RSK1/2 nor by MSK1.

Ser276 on p65 is important for IL- $1 \beta$-induced, NFkB-mediated gene expression

p65 can be phosphorylated on Ser529, Ser536 and Ser276 after exposure to various stimuli. To examine the importance of these residues for NFKB activity in beta cells we took advantage of the Gal4-one-hybrid approach. Cells transfected with wild-type p65, and plasmids expressing p65 mutated in Ser536 (p65S536A) or Ser529 (p65S529A), responded equally well to IL-1 $\beta$ exposure.

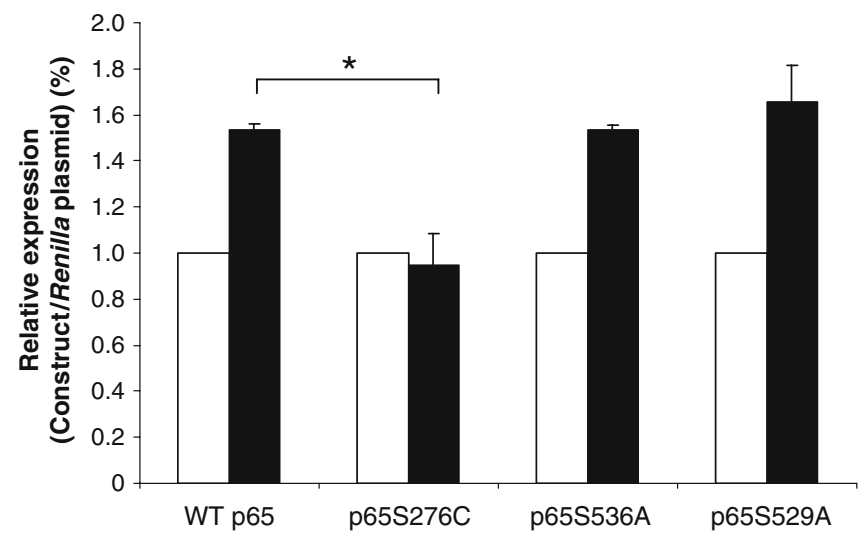

Fig. 5 Importance of different serine residues for IL- $1 \beta$-induced NFKB-mediated gene transcription. INS-1E cells were transiently transfected with a Gal4/luciferase construct, a control Renilla plasmid and expression plasmids encoding the Gal4 DNA-binding domain fused to the transactivating domain of p65, the latter in wildtype form (WT p65) or with serines mutated at position 276, 536 or 529 . Cells were subsequently exposed to IL-1 $\beta(320 \mathrm{pg} / \mathrm{ml})$ for $6 \mathrm{~h}$ (black bars). Data are presented as mean $\pm \operatorname{SEM}(n=3) . * p<0.05$ vs IL-1 $\beta$-stimulated wild-type transfected cells ( $t$ test) 
However, mutating Ser276 on p65 completely abrogated the effect of IL-1 $\beta$ on gene expression. This residue is therefore essential for IL-1 $\beta$-induced NF KB-mediated gene expression (Fig. 5).

\section{Discussion}

Among the numerous binding sites for various transcription factors found in the Nos 2 promoter, the proximal NFKB binding site seems decisive for Nos 2 mRNA transcription in beta cells [38]. The MAPKs ERK and p38 are also critical for IL-1 $\beta$-induced Nos 2 expression [1] but the interaction between these two signalling pathways has not previously been investigated in beta cells. By using a systematic approach in which each individual MAPK was blocked and IL-1 $\beta$-induced NFKB and Nos 2 activation was determined, we show here that ERK is the primary MAPK involved in the potentiation of NFKB-mediated gene transcription in insulin-producing cells. Our present data strongly suggest that ERK-mediated iNOS regulation is caused by increasing NFKB transactivation, suggesting the novel concept that MAPK regulates NFKB activation in beta cells.

The use of pharmacological inhibitors is a powerful tool for dissecting the role of protein kinases in cellular signalling. However, such compounds are often known to be selective rather than specific to their established targets, affecting the activity of few or several other protein kinases, although often with much lower potency. SB203580 and PD98059 are well-characterised protein kinase inhibitors. Davies et al. [43] tested the specificity of some of the commonly used protein kinase inhibitors against a large panel of protein kinases, and concluded that, among the battery of commercially available compounds tested, PD98059 and SB203580 were among those with the most impressive selective profile. We have shown previously and in this study that PD98059 and SB203580 inhibit their established targets without inhibiting any of the other highly conserved members of the MAPK family when analysed by kinase assays using insulin-secreting cell lines and primary rat islets [1, 6 and data not shown].

Rapidly dividing cell lines may have a requirement for basal MAPK activity to grow and proliferate, and MAPK inhibition may have cytostatic and cytotoxic effects on such cell lines. However, the INS-1E cell line divides slowly and we did not observe toxic effects with the relatively short-term exposure periods used, as assessed by morphology or the proliferation of the cell cultures (data not shown). Besides being a glucose-sensitive clonal beta cell line, INS-1E cells also resemble primary beta cells in that they have low basal ERK activity that can be induced to increase by even moderate IL- $1 \beta$ concentrations compared with other beta cell lines. We previously reported that MAPK inhibition prevented IL- $1 \beta$-induced reduction in insulin release, NO production and Nos2 expression in intact rat islets [1], and we therefore believe that our present findings are representative of the situation in primary cells.
Decreasing NFKB-mediated gene expression by blocking the activity of ERK is apparently not sufficient to block iNOS protein production (present data) and NO formation. Further post-transcriptional mechanisms of regulation, such as mRNA stabilisation, may fine-tune the amount of cellular iNOS, as has been reported for $\mathrm{p} 38$ in other cell types $[44,45]$.

As is the case for the activity of many other transcription factors, that of $\mathrm{NFKB}$ is regulated by transcriptional coregulators $[31,46]$. Co-regulators function by both bridging the sequence-specific activators to the basal transcriptional machinery and by remodelling chromatin structure. p65 is able to interact with the co-activators CREB-binding protein (CBP), its structural homologue p300 and PCAF (p300/ CBP-associated factor), an interaction leading to acetylation of p65 and generally associated with potentiation of NFKBdependent transcriptional activity $[31,46]$. This NFkB/coactivator interaction is dependent upon the stimulus-induced phosphorylation of p65 [20, 31].

IKB kinase (IKK), Akt (also known as protein kinase B) and NFKB-activating kinase have all been shown to phosphorylate Ser536 on p65 [23, 25, 27, 29]. Casein kinase II phosphorylates Ser529, whereas the specific residue for GSK-3 $\beta$ is unknown [32, 47]. In the present work we tested three serine-mutated forms of p65, but only the Ser276-mutant abrogated IL-1 $\beta$-induced gene expression in INS-1E cells. MSK1 has recently been identified as the TNF $\alpha$-induced p38-and ERK-activated nuclear kinase for p65, capable of associating with and phosphorylating p65 at Ser276 [22]. Phosphorylation and the subsequent conformational changes of $\mathrm{p} 65$ are required for functional synergy between p65 and co-factors, since access to CBP/ p300 interaction regions in unphosphorylated p65 are blocked by intramolecular masking of the $\mathrm{N}$-terminal region of $\mathrm{p} 65$ by the $\mathrm{C}$-terminal region [31]. We excluded both MSK1 and its homologous kinase RSK as kinases responsible for IL- $1 \beta$-induced, ERK-mediated activation of NFKB. Accordingly, Okazaki and colleagues found that IKK, GSK-3 $\beta$, NFkB-activating kinase and Akt were incapable of phosphorylating Ser276 in an in vitro kinase assay in murine embryonic fibroblasts [48]. PKAc is another Ser276-specific kinase that enhances NFkB DNA binding and association with CBP, causing increased NFKB-dependent transcription [19, 31]. However, Okazaki et al. found that recombinant PKAc phosphorylated GSTp65(1-305) very poorly, and failed to do so when transiently expressed in HEK293 cells [48]. As PKA is not involved in cytokine signalling in beta cells, it can also be ruled out as the responsible kinase in our system. These observations imply the presence of both cell-specific and stimulus-dependent mechanisms of NFKB activation. Additional mechanisms, e.g. a novel unidentified Ser276 kinase or other post-translational modifications of $\mathrm{p} 65$, such as acetylation, may contribute to the effect of ERK on NFKB transactivity in beta cells.

The fact that ERK augmented NFKB-mediated gene transcription without influencing $\mathrm{I} \kappa \mathrm{B} \alpha$ degradation or NFKB DNA binding adds to the accumulating evidence suggesting that signalling pathways independent of IKB 
degradation, nuclear translocation or DNA binding of NFKB are required for the full transcriptional activity of $\mathrm{NF} \kappa \mathrm{B}[21,23,49]$. This is similar to the regulation of other transcription factors, which are often regulated through the phosphorylation of the transcription factor itself [50].

Based on the present results, we propose a model in which IL-1 $\beta$-induced ERK activation leads to post-translational modifications of Ser276 of p65 by a yet unidentified kinase. This leads to the recruitment of cofactors such as $\mathrm{CBP} / \mathrm{p} 300$ that alter gene expression by an acetylation-dependent effect on the transactivating potential of NFKB and/or the chromatin structure of NFKBresponsive genes. Ultimately, this complex crosstalk will shift the balance of gene expression in a direction favouring beta cell dysfunction and death. Understanding the role of the different components of the NFKB/MAPK pathways, and the means by which they interact with each other, will hopefully allow us to modulate this network and thus prevent beta cell apoptosis.

Acknowledgements We thank A.-S. Hillesø for excellent technical assistance, and are grateful to $\mathrm{M}$. Frödin (BRIC, Copenhagen, Denmark) for providing us with plasmids encoding various forms of the RSK members. This work was financially supported by grants from the Danish Diabetes Association, Novo Nordisk, a scholar stipend from the University of Copenhagen, the Fonds National de la Recherche Scientifique (FNRS) and Action de Recherche Concentré (ARC), Belgium. This work has been conducted in collaboration with and with the support of the JDRF Center for Prevention of $\beta$ Cell Destruction in Europe under grant number 4-2002-457.

\section{References}

1. Larsen CM, Wadt KA, Juhl LF et al (1998) Interleukin-1betainduced rat pancreatic islet nitric oxide synthesis requires both the p38 and extracellular signal-regulated kinase 1/2 mitogenactivated protein kinases. J Biol Chem 273:15294-15300

2. Sandler S, Andersson A, Hellerstrom C (1987) Inhibitory effects of interleukin 1 on insulin secretion, insulin biosynthesis, and oxidative metabolism of isolated rat pancreatic islets. Endocrinology 121:1424-1431

3. Mandrup-Poulsen T, Bendtzen K, Nerup J, Dinarello CA, Svenson M, Nielsen JH (1986) Affinity-purified human interleukin I is cytotoxic to isolated islets of Langerhans. Diabetologia 29:63-67

4. Welsh N, Eizirik DL, Bendtzen K, Sandler S (1991) Interleukin-1 beta-induced nitric oxide production in isolated rat pancreatic islets requires gene transcription and may lead to inhibition of the Krebs cycle enzyme aconitase. Endocrinology 129:3167-3173

5. Bonny C, Oberson A, Steinmann M, Schorderet DF, Nicod P, Waeber G (2000) IB1 reduces cytokine-induced apoptosis of insulin-secreting cells. J Biol Chem 275:16466-16472

6. Ammendrup A, Maillard A, Nielsen K et al (2000) The c-Jun amino-terminal kinase pathway is preferentially activated by interleukin-1 and controls apoptosis in differentiating pancreatic beta-cells. Diabetes 49:1468-1476

7. Eizirik DL, Mandrup-Poulsen T (2001) A choice of death-the signal-transduction of immune-mediated beta-cell apoptosis. Diabetologia 44:2115-2133

8. Nikulina MA, Sandhu N, Shamim Z et al (2003) The JNK binding domain of islet-brain 1 inhibits IL-1 induced JNK activity and apoptosis but not the transcription of key proapoptotic or protective genes in insulin-secreting cell lines. Cytokine 24:13-24
9. Hoorens A, Stange G, Pavlovic D, Pipeleers D (2001) Distinction between interleukin-1-induced necrosis and apoptosis of islet cells. Diabetes 50:551-557

10. Giannoukakis N, Rudert WA, Trucco M, Robbins PD (2000) Protection of human islets from the effects of interleukin-1beta by adenoviral gene transfer of an Ikappa B repressor. J Biol Chem 275:36509-36513

11. Mandrup-Poulsen T (2001) Beta-cell apoptosis: stimuli and signaling. Diabetes 50:S58-S63

12. Pavlovic D, Andersen NA, Mandrup-Poulsen T, Eizirik DL (2000) Activation of extracellular signal-regulated kinase (ERK) $1 / 2$ contributes to cytokine-induced apoptosis in purified rat pancreatic beta-cells. Eur Cytokine Netw 11:267-274

13. Andersen NA, Larsen CM, Mandrup-Poulsen T (2000) TNF alpha and IFNgamma potentiate IL-1beta induced mitogen activated protein kinase activity in rat pancreatic islets of Langerhans. Diabetologia 43:1389-1396

14. Saldeen J, Lee JC, Welsh N (2001) Role of p38 mitogenactivated protein kinase (p38 MAPK) in cytokine-induced rat islet cell apoptosis. Biochem Pharmacol 61:1561-1569

15. Bonny C, Oberson A, Negri S, Sauser C, Schorderet DF (2001) Cell-permeable peptide inhibitors of JNK: novel blockers of beta-cell death. Diabetes 50:77-82

16. Baldwin AS (1996) The nf-kappa-b and i-kappa-b proteinsnew discoveries and insights. Annu Rev Immunol 14:649-683

17. Saldeen J, Welsh N (1994) Interleukin-1 beta induced activation of NF-kappa B in insulin producing RINm5F cells is prevented by the protease inhibitor $\mathrm{N}$ alpha- $p$-tosyl-L-lysine chloromethylketone. Biochem Biophys Res Commun 203:149 155

18. Flodstrom M, Welsh N, Eizirik DL (1996) Cytokines activate the nuclear factor kappa B (NF-kappa B) and induce nitric oxide production in human pancreatic islets. FEBS Lett 385:4 6

19. Zhong H, SuYang H, Erdjument-Bromage H, Tempst P, Ghosh $\mathrm{S}$ (1997) The transcriptional activity of NF-kappaB is regulated by the IkappaB-associated PKAc subunit through a cyclic AMP-independent mechanism. Cell 89:413-424

20. Zhong H, May MJ, Jimi E, Ghosh S (2002) The phosphorylation status of nuclear NF-kappa B determines its association with $\mathrm{CBP} / \mathrm{p} 300$ or HDAC-1. Mol Cell 9:625-636

21. Wang D, Baldwin AS Jr (1998) Activation of nuclear factorkappaB-dependent transcription by tumor necrosis factor-alpha is mediated through phosphorylation of RelA/p65 on serine 529. J Biol Chem 273:29411-29416

22. Vermeulen L, De Wilde G, Van Damme P, Vanden Berghe W, Haegeman G (2003) Transcriptional activation of the NFkappaB p65 subunit by mitogen- and stress-activated protein kinase-1 (MSK1). EMBO J 22:1313-1324

23. Sizemore N, Leung S, Stark GR (1999) Activation of phosphatidylinositol 3-kinase in response to interleukin-1 leads to phosphorylation and activation of the NF-kappaB p65/RelA subunit. Mol Cell Biol 19:4798-4805

24. Schmitz ML, dos Santos Silva MA, Baeuerle PA (1995) Transactivation domain 2 (TA2) of p65 NF-kappa B. Similarity to TA1 and phorbol ester-stimulated activity and phosphorylation in intact cells. J Biol Chem 270:15576-15584

25. Sakurai H, Chiba H, Miyoshi H, Sugita T, Toriumi W (1999) IkappaB kinases phosphorylate NF-kappaB p65 subunit on serine 536 in the transactivation domain. J Biol Chem 274:30353-30356

26. Bird TA, Schooley K, Dower SK, Hagen H, Virca GD (1997) Activation of nuclear transcription factor NF-kappaB by interleukin-1 is accompanied by casein kinase II-mediated phosphorylation of the p65 subunit. J Biol Chem 272:3260632612

27. Mattioli I, Sebald A, Bucher C et al (2004) Transient and selective NF-kappa B p65 serine 536 phosphorylation induced by $\mathrm{T}$ cell costimulation is mediated by I kappa B kinase beta and controls the kinetics of p65 nuclear import. J Immunol 172:6336-6344 
28. Hu J, Nakano H, Sakurai H, Colburn NH (2004) Insufficient p65 phosphorylation at S536 specifically contributes to the lack of NF-kappaB activation and transformation in resistant JB6 cells. Carcinogenesis 25:1991-2003

29. Fujita F, Taniguchi Y, Kato T et al (2003) Identification of NAP1, a regulatory subunit of IkappaB kinase-related kinases that potentiates NF-kappaB signaling. Mol Cell Biol 23:7780 7793

30. Duran A, Diaz-Meco MT, Moscat J (2003) Essential role of RelA Ser311 phosphorylation by zetaPKC in NF-kappaB transcriptional activation. EMBO J 22:3910-3918

31. Zhong H, Voll RE, Ghosh S (1998) Phosphorylation of NFkappa B p65 by PKA stimulates transcriptional activity by promoting a novel bivalent interaction with the coactivator $\mathrm{CBP} /$ p300. Mol Cell 1:661-671

32. Chantome A, Pance A, Gauthier N et al (2004) Casein kinase II-mediated phosphorylation of NF-kappaB p65 subunit enhances inducible nitric-oxide synthase gene transcription in vivo. J Biol Chem 279:23953-23960

33. Vanden Berghe W, Plaisance S, Boone E et al (1998) p38 and extracellular signal-regulated kinase mitogen-activated protein kinase pathways are required for nuclear factor-kappaB p65 transactivation mediated by tumor necrosis factor. J Biol Chem 273:3285-3290

34. Beyaert R, Cuenda A, Vanden Berghe W et al (1996) The p38/ RK mitogen-activated protein kinase pathway regulates interleukin-6 synthesis response to tumor necrosis factor. EMBO J 15:1914-1923

35. Mandrup-Poulsen T (2003) Beta cell death and protection. Ann N Y Acad Sci 1005:32-42

36. Roenn SG, Hansen JA, Lindberg K, Karlsen AE, Billestrup N (2002) The effect of suppressor of cytokine signaling 3 on GH signaling in beta-cells. Mol Endocrinol 16:2124-2134

37. Asfari M, Janjic D, Meda P, Li G, Halban PA, Wollheim CB (1992) Establishment of 2-mercaptoethanol-dependent differentiated insulin-secreting cell lines. Endocrinology 130:167178

38. Darville MI, Eizirik DL (1998) Regulation by cytokines of the inducible nitric oxide synthase promoter in insulin-producing cells. Diabetologia 41:1101-1108

39. Frodin M, Jensen CJ, Merienne K, Gammeltoft S (2000) A phosphoserine-regulated docking site in the protein kinase RSK2 that recruits and activates PDK1. EMBO J 19:29242934
40. Kristof AS, Marks-Konczalik J, Moss J (2001) Mitogenactivated protein kinases mediate activator protein-1-dependent human inducible nitric-oxide synthase promoter activation. J Biol Chem 276:8445-8452

41. Keinanen R, Vartiainen N, Koistinaho J (1999) Molecular cloning and characterization of the rat inducible nitric oxide synthase (iNOS) gene. Gene 234:297-305

42. Frodin M, Gammeltoft S (1999) Role and regulation of $90 \mathrm{kDa}$ ribosomal S6 kinase (RSK) in signal transduction. Mol Cell Endocrinol 151:65-77

43. Davies SP, Reddy H, Caivano M, Cohen P (2000) Specificity and mechanism of action of some commonly used protein kinase inhibitors. Biochem J 351:95-105

44. Clark AR, Dean JL, Saklatvala J (2003) Post-transcriptional regulation of gene expression by mitogen-activated protein kinase p38. FEBS Lett 546:37-44

45. Tebo J, Der S, Frevel M, Khabar KS, Williams BR, Hamilton TA (2003) Heterogeneity in control of mRNA stability by AUrich elements. J Biol Chem 278:12085-12093

46. Chen LF, Mu Y, Greene WC (2002) Acetylation of RelA at discrete sites regulates distinct nuclear functions of NF-kappaB. EMBO J 21:6539-6548

47. Schwabe RF, Brenner DA (2002) Role of glycogen synthase kinase-3 in TNF-alpha-induced NF-kappaB activation and apoptosis in hepatocytes. Am J Physiol Gastrointest Liver Physiol 283:G204-G211

48. Okazaki T, Sakon S, Sasazuki T et al (2003) Phosphorylation of serine 276 is essential for p65 NF-kappaB subunit-dependent cellular responses. Biochem Biophys Res Commun 300:807812

49. Madrid LV, Wang CY, Guttridge DC, Schottelius AJ, Baldwin AS Jr, Mayo MW (2000) Akt suppresses apoptosis by stimulating the transactivation potential of the RelA/p65 subunit of NF-kappaB. Mol Cell Biol 20:1626-1638

50. Whitmarsh AJ, Davis RJ (2000) Regulation of transcription factor function by phosphorylation. Cell Mol Life Sci 57:11721183 